\title{
HOW TO HARVEST THE ANTEROLATERAL THIGH FREE FLAP
}

\author{
Parintosa Atmodiwirjo1, Mohamad Rachadian Ramadan¹, Sara Ester Triatmoko1,Nadhira Anindita Ralena²
}

1. Reconstructive Microsurgery Section, Division of Plastic Surgery, Faculty of Medicine Universitas Indonesia, dr. Cipto Mangunkusumo National Hospital. Jakarta, Indonesia.

2. Faculty of Medicine, Universitas Indonesia. Jakarta, Indonesia

\begin{abstract}
Summary: The anterolateral thigh (ALT) flap is the flap with various components based on perforators from descending branch of the lateral circumflex femoral artery. This flap has number of advantages and disadvantages. It can be used to reconstruct defect after oncologic resection and coverage following amputation or to preserve limb length. The contraindications includes, unsuitable donor site, inadequately debrided recipient site and morbid obesity. Preparations for ALT procedure consist of history taking, physical examinations and supporting examinations.

Keywords: Anterolateral Thigh Flap; Microsurgery; Reconstructive Microsurgery, Flaps

Ringkasan: Anterolateral thigh (ALT) flap adalah flap dengan berbagai komponen berdasarkan perforator cabang desendan dari arteri femoralis sirkumfleksa lateral. Flap ini sendiri memiliki sejumlah kelebihan dan kekurangan. ALT dapat digunakan dalam beberapa kasus, seperti untuk merekonstruksi defek setelah reseksi onkologis dan penutupan defek setelah amputasi atau untuk mempertahankan panjang ekstremitas. Kontraindikasinya meliputi lokasi donor yang tidak cocok, luka resipien yang tidak bersih dan obesitas morbid. Persiapan untuk prosedur $A L T$ terdiri dari anamnesis, pemeriksaan fisik, dan pemeriksaan penunjang.

Kata Kunci: Anterolateral Thigh Flap; Free flaps; Bedah mikro; Bedah mikro rekonstruksi
\end{abstract}

\section{Conflicts of Interest Statement:}

The author(s) listed in this manuscript declare the absence of any conflict of interest on the subject matter or materials discussed.

\section{SUPPORTING INFORMATION}

This is Video Article, additional supporting information may be found online on the JPRjournal Official YouTube channel: https://youtu.be/LUGR4u35fA4 


\section{INTRODUCTION}

The anterolateral thigh (ALT) flap is the flap with various components based on perforators from descending branch of the lateral circumflex femoral artery. The other name of ALT flap is descending branch of lateral circumflex femoral (LCF) artery perforator flap. ${ }^{1}$

The ALT flap has several advantages. The flap acts the most preferred donor sites for soft tissue reconstruction. Its thickness and volume could also be adjusted depends on the defect. This flap has a wide indication for resurfacing a defect and various components could be included based on the defect needs, including ultrathin skin flaps to musculocutaneous vastus lateralis and extensive chimeric flaps. The donor site of ALT flap can be closed by primary suture if the width of the flap is not more than $8 \mathrm{~cm}$. This flap does not result to significant functional or aesthetic deterioration of the lower leg. ${ }^{1}$

Nevertheless, the ALT flap has some disadvantages, such as possible variations in vascular anatomy and the course and location of the main cutaneous perforator, as well as possible absence of cutaneous branches or perforator. The veins may also show different backflow strength, so venous return should be checked before anastomosis. The thickness of the flap can be disadvantageous for intraoral defect and splitthickness skin graft is needed to close the donor site, if $>8 \mathrm{~cm}$ of tissue is taken. ${ }^{1}$

\section{INDICATIONS}

There are several indications in conducting ALT free flap procedure, such as reconstruction after oncologic resection, coverage of open fractures and non-unions, coverage for salvage of compromised joint replacements, coverage following amputation or to preserve limb length, as well as soft-tissue coverage of exposed bone, tendon, implants, or vital structures. ALT flap may also be indicated in softtissue coverage of osteomyelitis or treated infection. $2,3,4,5$

\section{CONTRAINDICATIONS}

Meanwhile ALT free flap also has several contraindications, such as unsuitable donor site, inadequately debrided wounds or unstable wound bed, morbid obesity, dysvascular limb, prohibitive medical comorbidities, and unwillingness to accept donor site.

\section{PREPARATIONS}

Prior to the surgery, there are several steps to be conducted. These procedures are required to ensure whether or not the patients have the contraindications of the surgery. ${ }^{1}$

In history taking, identification of vascular diseases such as: peripheral vascular disease, deep vein thrombosis, venous stasis disease, arteritis should be done. Previous surgery and previous trauma in donor area should also be identified. ${ }^{1,6}$

Physical examinations include body mass index, skin diseases at the thigh area and infection of the thigh soft tissue. ${ }^{1}$ Supporting examinations may include CT-Angiography, if only there is previous trauma history on the donor site, color doppler ultrasonography, and sound doppler. ${ }^{1}$

\section{SUMMARY}

Anterolateral Thigh (ALT) free flap is the flap with various components based on perforators from descending branch of the lateral circumflex femoral artery. Indications and contraindications should be accounted prior to surgery through history taking, physical examinations and supporting examinations.

\section{Correspondence regarding this article should be addressed to: \\ Parintosa Atmodiwirjo, MD. \\ Reconstructive Microsurgery Section, Division of Plastic \\ Surgery, Dr. Cipto Mangunkusumo National Hospital, Universitas Indonesia. Jakarta 12310, Indonesia. \\ E-Mail: parintosa.atmodiwirjo@ui.ac.id}

\section{REFERENCES}

1. Atmodiwirjo P, Triatmoko SE. How To Harvest The Free Osteoseptocutaneous Fibular Flap: Step-by-Step. Jakarta: Lingkar Studi Bedah Plastik; 2019

2. Samra F, Bibbo C, Levin LS, Kovach SJ. A Practical Guide to the Use of the Anterolateral Thigh Flap. JBJS Essent Surg Tech. 2017;7(3):22.

3. Khadakban D, Kudpaje A, Thankappan K, et al. Reconstructive Indications of Anterolateral Thigh Free Flaps in Head and Neck Reconstruction. Craniomaxillofac Trauma Reconstr. 2016;9(1):40-5.

4. Atmodiwirjo P, Mukarramah D. A Thin Anterolateral Thigh Free Flap for Severe 
Hand Burn Deformity. Jurnal Plastik Rekonstruksi. 2012;1(3).

5. Ramadan MR, Ralena NA, Triatmoko SE, Atmodiwirjo P. Early And Recent Development Of Reconstructive Microsurgery Subspeciality In Dr. Cipto Mangunkusumo National Hospital,
Universitas Indonesia (1983-2020). Jurnal Plastik Rekonstruksi. 2020;6(2):281-90.

6. Atmodiwirjo P, Sandhi A. Microsurgery Technique in the Foot Reconstruction of Soft Tissue Defects: A Review of 4 Cases. Jurnal Plastik Rekonstruksi. 2012;1(1). 